Chapter 14

\title{
Environmental Role of Earthworm (Lumbricidae) in Formation of Soil Buffering Capacity Against Copper Contamination in Remediated Soil, Steppe Zone of
}

\section{Ukraine}

\author{
Loza Iryna, Kul'bachko Yurii, Didur Oleg and \\ Kryuchkova Angelina
}

Additional information is available at the end of the chapter

http://dx.doi.org/10.5772/64722

\begin{abstract}
The study allowed effect of earthworm casting activities on soil buffering against copper compounds within the territory remediated after coal mining (Western Donbass, Ukraine). Assay of copper immobilization/mobilization was performed in earthworm casts (excretions) and artificial remediated soil. Efficiency of immobilization in the casts (humus-free and humic variants) was more (23 and $43 \%$, respectively) than efficiency of immobilization in the initial soil: loess-like loam and chernozem (19.9 and 40.1\%, respectively). Thus, earthworm ecoservice activity changed positively environmental conditions of remediated soil and naturalization of artificial edaphotopes within remediated lands in steppe zone. Environmental quality of remediated soil enriched in earthworm casts was confirmed to be improved.
\end{abstract}

Keywords: contaminated soil, earthworm vital activity, remediated soil, buffering capacity, copper contamination, sustainable development

\section{Introduction}

Environmental protection, natural resource management, ensuring of environmental safety of human life are essential conditions for sustainable economic and social development of the European countries. Among the densely populated areas in the steppe zone of Ukraine, 
Dnipropetrovsk region is characterized by high level of metallurgic and agricultural production. Active mining extraction inevitably accompanied by diminishing of fertility in ordinary and southern chernozem, despite this soil has a great potential for agricultural exploitation. The harmfulness of such processes consists not only in reducing the square of arable land, but also in significant deterioration of ecological status on the entire territory within Dnieper steppe. As a result, increasing rate of coal extraction leads to enlargement of disturbed land area. The most significant changes are taking place with the land fund during development of coal deposits. Under such conditions, the soil cover degraded completely; new forms of relief and landscapes, having fundamental changes of properties and regimes were formed instead. Man-made landscapes connected with the activities of mining and smelting complex often formed by the low-biogenic phytotoxic rocks, this is part of the reason for their low biological productivity $[7,10,28]$.

Forest remediation is one of ways for optimization of such technogenic landscapes [1]. According to the modern concept of land remediation, forest remediation is carried out in the absence of reasonability to recycle the land for agricultural use. The main purposes of forest remediation are the forest fund increasing and improvement of environment. Environmentally, the main task of the forest remediation is creation of sustainable forest plantations that have a powerful environment-forming effect on technogenically disturbed sites $[4,8]$. Forest remediation is the most effective method to recovery disturbed lands under steppe conditions; after its performing will be a dramatic increase in the forest area of the damaged territory, because the forest provides a reliable water retention, reduces wind strength, redistributes better the summer and winter precipitation, conversion surface runoff waters into deep runoff waters, leveling of temperature regimes, etc. [5].

Since soil is the basis of any terrestrial ecosystem that determines direction of development and features of ecosystem functioning, the rate of its formation determines the rate of recovery of all other ecosystem components and functioning conditions (bacteria, plant and animal communities). Therefore, the efficiency of forest ecosystem recovery can be estimated by the rate of soil formation and environmental properties of the root layer created during the remediation process. We mean soil-forming process as the way of the initial substrate transformation by interaction of all soil-forming factors.

Decomposers, also referred to as reducers, are an important component of any ecosystem [21]. Among the decomposers, soil saprophages play a crucial role; their trophic activity causes environment-transforming (zoo pertinent) effect on artificial forest ecosystem within remediated lands, contributing to destruction of plant debris. They provide the ecosystem services such as waste recycling and detoxification, encouraging improvement of soil environment state. Healthy soil is one of the main conditions needed for successful growth of forest plantings within steppe territory and for maintenance of ecologically sustainable agricultural production. Healthy soil is a key point of condition for successful forest growth; it forms an environment for root zone stimulating of soil biota activity and allows the roots to spread maximally within soil space.

Coal industry activity is considered to be one of the most powerful factors leading to deterioration of natural landscapes variety. Steppe zone of Ukraine comprises a major coal-mining 
area: the Donetsk Coal Basin (Donbass). When deeply buried deposits of Cretaceous period are moved onto the surface, it initiated the processes of physical weathering, oxidation, dissolution, hydrolysis, and burning. A number of other negative factors are also determined, such as high concentration of soluble toxic salts, heavy metal contamination, alkalinity level rise, low absorbency and permeability, high spoil density, low carbon, and plant-available nitrogen. For example, coal wastes contain organic and mineral substances with a high content of some elements threat to human health ( $\mathrm{Ni}, \mathrm{V}, \mathrm{Mn}, \mathrm{Cu}$, etc.); it leads to formation of the phytotoxic flows at water erosion, and strong aerial technogenic pollution at deflation, causing negative effect on all living organisms [22, 23].

Among all biota, soil mezofauna plays a crucial role in development of the resistance mechanisms in artificial forest plantations; in particular, representatives of the saprotrophic complex (earthworms) contribute greatly in such process. These invertebrates effect significantly to transformation of soil properties because their tropho-metabolic activities, acting as a biological factor in soil organic farming. Such invertebrates are called 'ecosystem engineers' and are able to influence the habitat and soil biota community through this activity; they can cause ecosystem succession [11, 25]. Among soil invertebrates, earthworms have a leading role in formation of stability mechanisms in soil. As a result of their life activity, earthworms make a significant ecological contribution to transformation of soil characteristics and properties. Tropho-metabolic activity of earthworms is considered to be an important element in formation of soil environmental properties that cause maintaining of buffer properties in artificial soil against copper contamination within remediated areas.

Copper (Cuprum, $\mathrm{Cu}$ ) is the chemical element of the first group in Mendeleev's periodic law. Serial number: 29, atomic mass: 63.54. Copper content in the Earth's crust is about $0.01 \%$. It is found in a free state in the form of nuggets that sometimes attain a large size (up to several tons). However, native copper ore is relatively uncommon, and currently it is produced not more than $5 \%$ of copper from the total world production. Copper is a sulphophilous (chalcophilous) element; $80 \%$ of it is present in the Earth's crust in the form of compounds with sulfur $[6,12]$. The average copper content (according to A. P. Vinogradov and D. M. Malyuga) in the lithosphere is $47 \mathrm{mg} / \mathrm{kg}$, in soil from 6 to $75 \mathrm{mg} / \mathrm{kg}$, in plant tissues from 2 to $70 \mathrm{mg} / \mathrm{kg}$. Among the sedimentary parent rocks, the highest content of copper is characteristic of the loess, loesslike loams and clays of different origin (20-25 mg of Cu per $1 \mathrm{~kg}$ of soil), the least - sands (5$12 \mathrm{mg} / \mathrm{kg}$ ) [14, 27]. Regional clark of copper in soil of the steppe zone in Ukraine is equal to 27 $\mathrm{mg} / \mathrm{kg}$ with a range of variation $10-64 \mathrm{mg} / \mathrm{kg}$ [3].

The share of mobile forms of copper compounds in the upper horizon of soils of the European part of the CIS countries is on average 10-12\% of its total content [29]. Red soil and yellow Podzolic soil are better provided with copper; sandy soil and soil enriched in organic matter contain smaller amounts of copper [15]. Humic substances are involved in the fixation of copper by soil [16]. Copper usually accumulates within the upper soil horizons, reflecting its bioaccumulation and contemporary technogenesis. Contamination by copper is the result of usage of substances containing this element, particularly of fertilizers, agricultural and municipal wastes. Enterprises of nonferrous metallurgy are significant sources of soil pollution with copper, in addition. 
Plants accumulate most of copper into their leaves and seeds, less in roots, and very little in stems [13]. Copper is a component of numerous enzymes insuring normal cells functioning; it takes part in process of chlorophyll formation and other oxidation-reduction processes into plant cells. Copper deficiency in plants causes lowering activity of synthetic processes and leads to accumulation of soluble carbohydrates, amino acids, and other degradation products of complex organic substances; such process leads to withering, turgor loss, chlorosis, delayed shooting stage, and poor seed formation [2]. In animals, copper involved in processes of enzyme activation and it is part of the respiratory proteins such as hemoglobin and hemocyanin [22]. Living organisms-concentrators of copper are well known among both plants and animals (tea plant, mollusks, spiders, etc.). Many animals and plants experience toxicity from copper excess [19]. In most cases, trace elements (particularly copper) come to the animals through trophic chains. Considering representatives of saprophages, it should be noted that copper as a trace element is always presented in their body and excreta [17].

The goal of the article was evaluation earthworm (Lumbricidae) tropho-metabolic effect in maintaining capacity of remediated artificial soil to resist from copper contamination. This paper determines quantitatively buffer capacity of artificial soil and earthworm casts from copper contamination, and make a comparison of immobilization capacity between earthworm casts and remediated soil. Soil buffering capacity is maintaining the chemical soil state unchanged under the influence of chemical compounds flow. Assessments of rates of Lumbricidae impact on the environment, particularly the effect of tropho-metabolic activity of earthworms on buffer capacity of the remediated soil are of scientific and practical interest in relation to soil fertility management.

\section{Material and methods}

Site description. Field data were sampled by the investigators on the site of forest remediation in Western Donbass (Ukraine, Dnepropetrovsk region). Soil samples were collected at a depth of $0-10 \mathrm{~cm}$, and fresh excreta (casts) of earthworm Aporrectodea caliginosa (Savigny, 1826) were sampled at the surface on the remediation site in a plantation of Norway maple (Acer platanoides) (second and third variants of remediation). The first variant of remediation was represented by filling of mining spoil unsuitable for growth of arboreal plants. Top layer of the second variant sampled for assay was represented by humus-free loess-like loam; and top layer of the third variant was represented by a humic filling layer of ordinary chernozem (Figure 1).

Earthworm A. caliginosa is referred to endogeic soil worms. It is classified as a saprophage, secondary decomposer, nitrogen liberator, and humificator [20, 24].

General description of the forest vegetation and filling remediated soil on the site of mine dump forest recultivation located within the territory of the Western Donbass (Ukraine, Dnepropetrovsk oblast) is shown as follows:

First variant. Platform of dump mine spoil was coated with a layer of the same spoil $2 \mathrm{~m}$ in thickness. Such variant of remediation was created with the aim to identify environmental 
suitability or unsuitability of mining spoil for the forest plantation growing. By 2005, trees and bushes had been died off completely within this variant of remediation. Mine spoil of the Western Donbass is a mass heavy loamy in granulometric composition, consisting of aleurolites and argillites; it contains $16-20 \%$ of organic carbon. The mine spoil is unsuitable for plant growth in its physicochemical, water, air, and mechanical properties and composition. It is absolutely impermeable, have a higher density, hardness, viscosity, stickiness, and adhesiveness. Such spoil dries to cement condition, and when wet it turns into viscous clay with a high water capacity and lack of air. Agrochemically, mining spoil is represented by nitrogen-free compounds, with trace amount of phosphorus, potassium, calcium, magnesium, sulfur, iron, and minor-nutrient elements. Against this background, pyrite provides especially negative effect $(1.5 \%)$, contributing to decrease of actual acidity to 3.0 units. Fresh, thrown to the daylight surface, mine spoil has an evaporated residue of not more than $0.4 \%$.

Second variant. Type of forest growing conditions: $\mathrm{DL}_{0-1}$ (dryish loam). Stratigraphic structure of soil profile: loess-like loam: 0-50 cm; tertiary sand: $50-100 \mathrm{~cm}$; mine spoil: $100-700 \mathrm{~cm}$. Planting with Norway maple. Type of light structure: half-shade. Type of timber-stand: 10 N. m., height: 8-10 m, average trunk diameter: $100-120 \mathrm{~mm}$, crown closure: $0.6-0.7$. Litter from maple leaves is poorly developed; it is mainly accumulated between the tree lines in the relief depressions. The grass cover is missing.

Third variant. Type of forest growing conditions: $\mathrm{DL}_{0-1}$ (dryish loam). The remediated bulk soil has the following stratigraphical characteristics: humic topsoil of ordinary chernozem: 0$50 \mathrm{~cm}$; loess-like loam: 50-100 cm; tertiary sand: 100-150 cm; mine spoil: $150-700 \mathrm{~cm}$. Planting with Norway maple. Type of light structure: half-lightened. Type of timber-stand: 10 N. m., height: 8-10 m, average trunk diameter: $100-120 \mathrm{~mm}$, crown closure: $0.5-0.6$. The litter layer is well developed; leaves are almost completely decomposed. The topsoil is moist to the touch, well structured. With a depth of $30 \mathrm{~cm}$, it is compacted, occupied densely by maple roots to a depth of $50 \mathrm{~cm}$. The grass cover is missing.

Sampling and experimental procedures. Definition of zoogenic participation in the process of stability formation in soil as a saprophages habitat (earthworms, Lumbricidae) against contamination by copper was performed by adding different amounts of copper with it absorption from copper solutions. As the methodological basis, recommendations developed by researchers of the National Scientific Center 'Institute for Soil Science and Agrochemistry Research named after O.N. Sokolovsky' were applied [9, 26]. Air-dry sample specimens of soil and earthworm excreta (casts) were placed in cylindrical vessels, filled with a solution of copper sulfate pentahydrate $\mathrm{CuSO}_{4} 5 \mathrm{H}_{2} \mathrm{O}$ contained copper in scalar concentrations (from 5 to $40 \mathrm{mg} \mathrm{Cu} / \mathrm{L}$ ), in a ratio of weigh/solution of sulfate of 1/10; suspension has been stirred for $2 \mathrm{~h}$ and left to stand for 1 day and filtered. The remaining soil onto the funnel filter was transferred to a glass box and dried to air-dry state. Samples were selected from samples prepared in such manner to determination of mobile forms of copper compounds. As extractant, it used ammonium-acetate buffer $(\mathrm{pH}=4.8)$. Content of extractable copper was determined by the method of atomic spectrophotometry. Quantitative determination of area under curve that characterizes the sustainability of earthworm casts and soil to the flow of toxicant was performed by means of numerical integration using Simpson's formula [18]. 


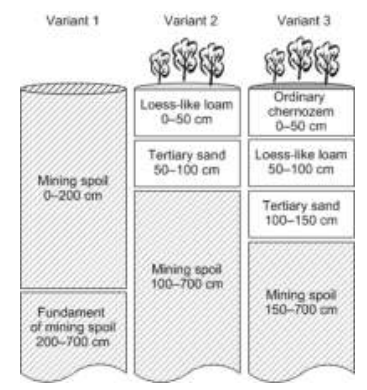

Figure 1. Variants of artificial soil in experimental-production area of forest reclamation and their stratigraphic structure.

To determine the zoogenic environmental-forming function in formation of soil resistance against copper contamination, we studied immobilization (immobility)-mobilization (mobility) of copper amount in earthworm casts and bulk soils, and participation of earthworm casts in formation of resistance against contamination with copper. To assess the impact of earthworms' tropho-metabolic activity for maintaining resistance of their habitats to copper pollution, we used effect and toxicant immobilization efficiency.

\section{Results and their discussion}

Effect of earthworm excreta (casts) on the soil resistance from flow of toxic agents such as high concentrations of copper was investigated on earthworm casts sampled in Norway maple planting. Graphic model of earthworm casts resistance to copper contamination (second and third variants of remediation) are represented in Figures 2 and 3. It indicates higher buffering capacity of casts in humus variant.

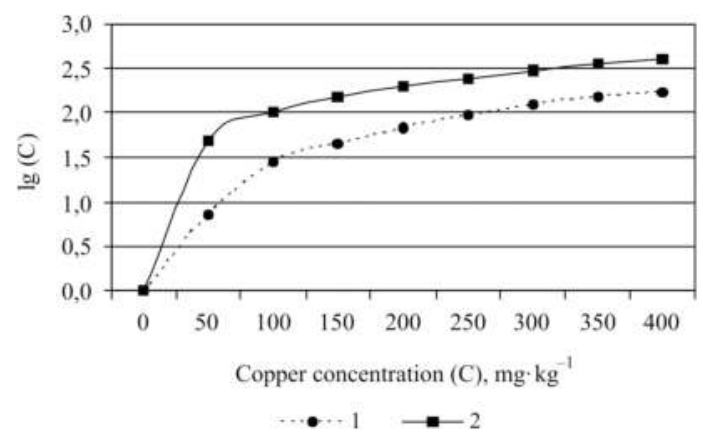

Figure 2. Graphic model of earthworm casts resistance to copper contamination (second variant, humus-free loess-like loam): 1 - Earthworm casts (humus-free loess-like loam, second variant); 2 - Reference. 


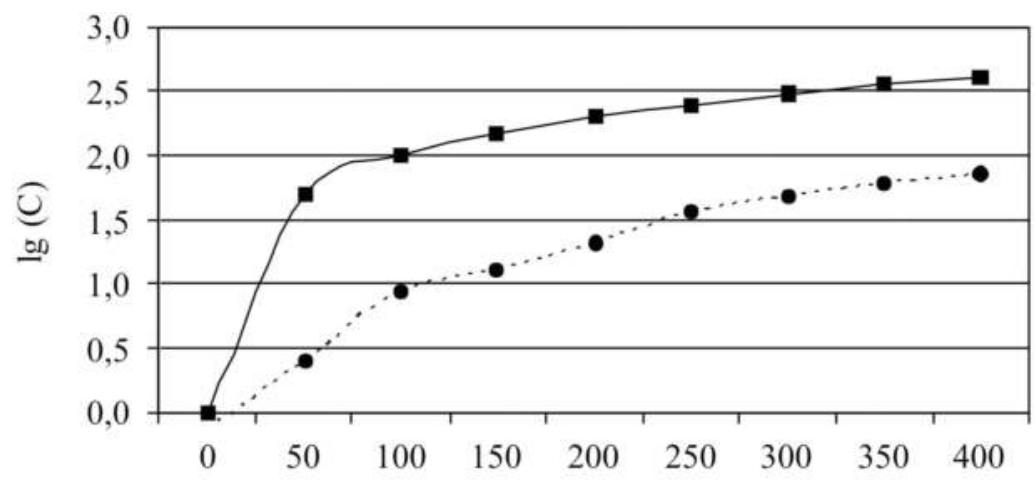

Copper concentration $(\mathrm{C}), \mathrm{mg} \cdot \mathrm{kg}^{-1}$

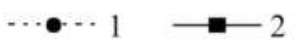

Figure 3. Graphic model of earthworm casts resistance to copper contamination (third variant, humic layer): 1 - Earthworm casts (humic layer, third variant); 2 - Reference.

\begin{tabular}{|c|c|c|c|c|c|}
\hline Characteristics & $\begin{array}{l}\text { Reference } \\
\text { area, nom. } \\
\text { units }\left(S_{\text {ref }}\right)\end{array}$ & $\begin{array}{l}\text { Sample area, } \\
\text { nom. units } \\
\left(\mathrm{S}_{\text {samp }}\right)\end{array}$ & $\frac{S_{\text {samp }}}{S_{\text {ref }}} \cdot 100$ & $\begin{array}{l}\text { Effect (S } \\
\left.\text { ref }-S_{\text {samp }}\right) \\
\text { nom. } \\
\text { units }\end{array}$ & $\begin{array}{l}\text { Effectiveness of toxicant } \\
\text { immobilization } \\
\frac{S_{\text {ref }}-S_{\text {samp }}}{S_{\text {ref }}} \cdot 100, \%\end{array}$ \\
\hline $\begin{array}{l}\text { Earthworm casts on humus- } \\
\text { free loess-like Loam (second } \\
\text { variant) }\end{array}$ & -857.1 & $659.6 \pm 1.55$ & 77.0 & 197.5 & 23.0 \\
\hline $\begin{array}{l}\text { Humus-free Loess-like } \\
\text { Loam (second variant) }\end{array}$ & 857.1 & $686.5 \pm 0.85$ & 80.1 & 170.6 & 19.9 \\
\hline $\begin{array}{l}\text { Earthworm casts on humus } \\
\text { layer of ordinary } \\
\text { Chernozem (third variant) }\end{array}$ & 857.1 & $483.7 \pm 5.65$ & 56.4 & 373.4 & 43.6 \\
\hline $\begin{array}{l}\text { Humus layer of ordinary } \\
\text { Chernozem (third variant) }\end{array}$ & 857.1 & $513.4 \pm 3.25$ & 59.9 & 343.7 & 40.1 \\
\hline
\end{tabular}

Table 1. Quantitative assessment of earthworm casts and soil resistance against copper contamination.

Results of the study show that in the range of $\mathrm{Cu}$ concentration from 50 to $400 \mathrm{mg}$, effect of casts $\left(S_{\text {ref }}-S_{\text {samp }}\right)$ on copper immobilization in the humus-free loess-like loam (second variant) was less than the effect of casts in the humic layer of ordinary chernozem (third variant), with a high level of statistical significance $(p=0.0011)$, and is 197.5 and 373.4 area units, respectively (Table 1). The effectiveness of immobilization that reflects resistance degree to contamination by this metal was increased from $23.1 \%$ (casts onto the humus-free loess-like loam) to $43.6 \%$ 
(casts on bulk humic layer from ordinary chernozem in the plantings of Norway maple). This, apparently, is due to the fact that the casts formed on loess-like loam is represented by the soilforming rock that contain no organic matter (particularly humus), while the earthworm casts that formed on filling humic layer includes soil organic matter. Furthermore, the presence of humic compositions in earthworm casts is a powerful factor in process of stability formation in remediated soil against the effects of toxic concentrations of copper.

In the context of soil-casts system, effect of casts $\left(S_{\text {ref }}-S_{\text {samp }}\right)$ on copper immobilization within concentration range of $\mathrm{Cu}$ from 50 to $400 \mathrm{mg}$ is more than the effect of initial bulk soil (respectively 170.6 and 197.5 area units on the second variant with humus-free loess-like loam; 343.7 and 373.4 area units on the third variant with humic layer of ordinary chernozem). In both cases, difference between average effects was statistically significant; values of significance level were 0.03 and 0.045 , respectively (Table 2).

Efficiency of immobilization in the studied casts (humus-free and humic variants) was more (23 and 43\%, respectively) than the efficiency of immobilization in the initial soil: loess-like loam and chernozem (19.9 and 40.1\% respectively, see Table 1). Efficiency of copper immobilization by casts compared with the corresponding initial soil (variants with loess-like loam and ordinary chernozem coating) was more by $3.1 \%$ (the difference between 23 and $19.9 \%$ ) and 3.5\%, respectively (the difference between 43.6 and $40.1 \%$ ). It evidences for the positive environment-forming role of earthworms (particularly their tropho-metabolic activity) in development of protective and buffer shield of remediated soils and enhances the immobilization ability of the zoogenic soil neoformations - casts - within sites of forest remediation. Thus, earthworm tropho-metabolic activity within different variants of forest remediation sites affects the soil immobilization capacity maintenance (buffering capacity to heavy metals, including copper).

\begin{tabular}{lllll}
\hline Item & $\begin{array}{l}\text { Casts (loess-like } \\
\text { loam, second } \\
\text { variant) }\end{array}$ & $\begin{array}{l}\text { Loess-like } \\
\text { loam, second } \\
\text { variant }\end{array}$ & $\begin{array}{l}\text { Casts (humic layer } \\
\text { of ordinary } \\
\text { Chernozem, third } \\
\text { variant) }\end{array}$ & $\begin{array}{l}\text { Humic layer of } \\
\text { ordinary } \\
\text { Chernozem, third } \\
\text { variant) }\end{array}$ \\
\hline $\begin{array}{l}\text { Casts (Loess-like loam, second } \\
\text { variant) }\end{array}$ & - & - & \\
$\begin{array}{l}\text { Loess-like loam, second variant } \\
\text { Casts (humic layer of ordinary }\end{array}$ & $0.03^{*}$ & 0.0011 & 0.0012 & - \\
$\begin{array}{l}\text { Chernozem, third variant) } \\
\text { Humic layer of Ordinary Chernozem, } 0.0006\end{array}$ & 0.0009 & 0.045 & - \\
third variant) & & & \\
\hline
\end{tabular}

Note: The table shows significance level to compare pairs of objects.

Table 2. Statistical evaluation of differences between effects of earthworm cast and bulk soil against copper contamination. 


\section{Conclusion}

Ecosystem effectiveness of vital activity of soil saprophages (earthworms, Lumbricidae) was shown to be effected for increasing of buffering capacity in remediated soil against copper contamination. Resistance from concentrations of copper was increased in casts within the following range: from humus-free loess-like loam to humic layer of ordinary chernozem.

Effectiveness of copper immobilization by earthworm casts increased from 3.1 to $3.5 \%$ in comparison with the initial remediated soil. Thus, efficiency of process of land remediation increases with enrichment by earthworm casts; it leads to improvement of ecological quality in remediated soil. Earthworm ecoservice activity changes positively environmental features of remediated soil and speed up naturalization of artificial edaphotopes within remediated lands in steppe zone.

\section{Author details}

Loza Iryna*, Kul'bachko Yurii, Didur Oleg and Kryuchkova Angelina

*Address all correspondence to: irinaloza23@gmail.com

Laboratory of Biological Monitoring, Research Institute of Biology, Oles Honchar

Dnepropetrovsk National University, Dnepropetrovsk, Ukraine

\section{References}

[1] Androkhanov, V.A. Effectiveness of the main reclamation technologies in Kuzbass. V.A. Androkhanov, Bulletin of Dnepropetrovsk Agrarian-Economical University. 2012. No. 1. Pp. 106-109.

[2] Anspock, P. I. Microfertilizers, P. I. Anspock. Russia, Leningrad: Agropromizdat, 1990. $71 \mathrm{p}$.

[3] Fateev, A. I. Background trace elements in soils of Ukraine. A. I. Fateev, V. Y. Paschenko, S. A., Baluk, et al. Ed. by A. I. Fateev, V. Y. Paschenko. Ukraine, Kharkov: NCS “Institute of Soil Science and Agrochemistry n.a. A. N. Sokolovskiy, 2003. 120 p.

[4] Barannik, L. P. Forest on the "industrial deserts". L. P. Barannik, A. M. Kalinin. Russia, Kemerovo: Kemerovo Book. Publish. House, 1976. 60 p.

[5] Belgard, A. L. Steppe forestry. A. L. Belgard. Russia, Moscow: Lesn. Industry, 1971.336 p.

[6] Beus, A. A. Environmental geochemistry. A. A. Beus, L. I. Grabovskaya, N. V. Tikhonova. Russia, Moscow: Nedra, 1976. 248 p. 
[7] Chibrik, T. S. Studies on the biological reclamation of disturbed lands in the Ural University. The 100th anniversary of the birth of V. V. Tarchevskiy. T. S. Chibrik, News of the Ural State University. 2005. No. 37. Pp. 92-100.

[8] Baluk, S. A. Concept of reclamation land disturbed by open-cut and underground mining. S. A. Baluk, L. V. Yeterevska, A. P. Trawleev, et al. Ukraine, Kiev: NSC 'Institute of Soil Science and Agrochemistry n.a. A. N. Sokolovskiy', 2012. 50 p.

[9] Truskavetsky, G. S. Current physico-chemical methods of soil science. G. S. Truskavetsky, Y. L. Tsapko, I. V. Pashchenko, N. F. Cheshko, et al. Ukraine, Kiev: NSC “Institute of Soil Science and Agrochemistry n. a. A. N. Sokolovskiy, 1999. 35 p.

[10] Seredina, V. P. Ecological aspects of biological recultivation of soils in Kuzbass technogenic ecosystems. V. P. Seredina, V. A. Androkhanov, T. P. Alekseeva, et al. Bulletin of the Tomsk State University. Biology. 2008. No. 2. Pp. 61-72.

[11] Eisenhauer, N. The action of an animal ecosystem engineer: Identification of the main mechanisms of earthworm impacts on soil microarthropods, N. Eisenhauer, Pedobiologia. 2010. Vol. 53, No. 6. Pp. 343-352.

[12] Vladimirov, A. M. Environmental protection. A. M. Vladimirov, Y. I. Lyakhin, L. T. Matveev, V. G. Orlov. Russia, Leningrad: Gidrometeoizdat, 1991. 423 p.

[13] Evstratyeva, T. M. Copper and its forms in the soil-plant system: Author's PhD abstract. T. M. Evstratyeva. Ukraine, Odessa, 1973. 19 p.

[14] Grindel, N. M. Photometric methods in soil analysis. N. M. Grindel. Russia, Moskow: MGU, 1982. 248 p.

[15] Kabata-Pendias, A. Trace elements in soils and plants. A. Kabata-Pendias, H. Pendias. Moscow: Mir, 1989. 439 p.

[16] Kovalsky, V. V. Trace elements in soils of the USSR. V. V. Kovalsky, A. Hadrian. Russia, Moscow: Nauka, 1970. 177 p.

[17] Marinussen, M. P. Cu accumulation in Lumbricus rubellus under laboratory conditions compared with accumulation under field conditions. M. P. Marinussen, S. E. Van der Zee, F. A. M. de Haan, Ecotoxicology and Environmental Safety. 1997. Vol. 36, No. 1. Pp. 17-26.

[18] Markushevich, A. I. Areas and logarithms. A. I. Markushevich. Russia, Moscow: Nauka, 1979. 64 p.

[19] Orlov, A. S. Biogeochemistry: Textbook. A. S. Orlov, O. S. Bezuglova, Russia, Rostov, n/ D: Phoenix, 2000. 320 p.

[20] Perel, T. S. Pattern and trends of the distribution of earthworms in the Fauna of the Soviet Union. T. S. Perel. Russia, Moscow: Nauka, 1979. 272 p. 
[21] Pianka E. Evolutionary ecology: Transl. from Engl. E. Pianka; ed. and with foreword M. S. Gilyarov. Russia, Moscow: Mir, 1981. 400 p.

[22] Pokarzhevskiy, A. D. Geochemical ecology of terrestrial animals. A. D. Pokarzhevskiy, Russia, Moscow: Nauka, 1985. 304 p.

[23] Safonov, A. I. Phytogeochemistry of copper in anthropogenically transformed environment. A. I. Safonov, Issues of Ecology and Nature Protection in Technogenic Region. Ukraine, Donetsk: DonNU, 2005. Vol. 5. Pp. 68-74.

[24] Striganova, B. R. Feeding of soil saprophages. B. R. Striganova. Russia, Moscow: Nauka, 1980. 244 p.

[25] Tiunov, A. V. Metabiosis in the soil system: Effect of earthworms on the structure and functioning of soil biota, Extended Absract of Doctoral (Biol.) Dissertation. A. V. Tiunov. Moscow: Severtsov Institute of Ecology and Evolution Russian Academy of Sciences, 2007. $44 \mathrm{p}$.

[26] Truskavetskiy, R. S. Buffering capacity of soils and their basic functions. R. S. Truskavetskiy. Ukraine, Kharkiv: Nove Slovo, 2003. 225 p.

[27] Tsvetkova, N. M. Content and distribution of copper in native and man-made soil within the Steppe of the Dnieper region. N. M. Tsvetkova, A. A. Dubina, S. M. Zamlila, Bulletin of Dnipropetrovsk National University. Biology. Ecology. 2009. Vol. 17, No. 3. Pp. 106-114.

[28] Uzbek, I. H. Nodule bacteria of alfalfa and sainfoin located within the technogenic dumps. Uzbek I. H., Gruntoznavstvo. 2009. Vol. 10, Nos. 1-2. Pp. 111-116.

[29] Zborischiuk, Y. N. Average content of boron, manganese, cobalt, copper, zinc, molybdenum, and iodine in soils of the European part of the USSR. Y. Zborischiuk, N. G. Zyrin, Agrochemistry. 1974. No. 3. Pp. 88-94. 
